CURRENT RESEARCH JOURNAL OF HISTORY

(ISSN -2767-472X)

VOLUME 03 ISSUE 01 Pages: 1-5

SJIF IMPACT FACTOR (2021: 5. 505)

OCLC - 1243560778 METADATA IF - 6.458

Crossref doi) 81 Google

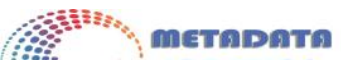

metapata 5 W WorldCat

Publisher: Master Journals

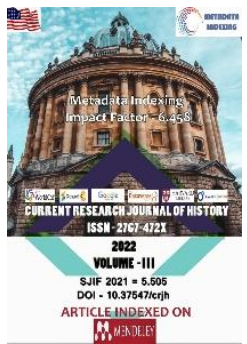

Journal Website: https://masterjournals. com/index.php/crih

Copyright: Original content from this work may be used under the terms of the creative commons attributes 4.0 licence.
Research Article

\section{THE HISTORY OF SPECIAL CAMPS IN GERMANY DURING THE SECOND WORLD WAR}

Submission Date: December 20, 2021, Accepted Date: January 01, 2022,

Published Date: January 10, 2022

Crossref doi: https://doi.org/10.37547/history-crjh-03-01-01

Fayzullayeva Klara Abdullayevna

Senior teacher of the Department of "History of Uzbekistan" of Jizzak Polytechnic Institute, Uzbekistan

\title{
ABSTRACT
}

The history of special camps in the Soviet zone is practically an aspect of the Soviet occupation policy in Germany that has not been studied in historiography. This article highlights and analyzes various aspects of the history of these special camps: the reason for their creation, the course of the deployment of the camp system during the Second World War, the nature of the contingent held in the camps, their staffing, as well as the place of special camps in the system of Soviet military administration bodies and their role in the activities of Soviet state security bodies in East Germany in the first post-war years.

\section{KEYWORDS}

Internment, Soviet military administration in Germany( SVAG), occupation policy of the USSR in Germany, Buchenwald, NKVD special camps/The Ministry of Internal Affairs in Germany, camps, Second World War, facilities. 
CURRENT RESEARCH JOURNAL OF HISTORY

(ISSN -2767-472X)

VOLUME 03 ISSUE 01 Pages: 1-5

SJIF IMPACT FACTOR (2021: 5. 505)

OCLC - 1243560778 METADATA IF - 6.458

Crossref do
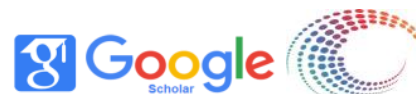

metaparn

Publisher: Master Journals

\section{INTRODUCTION}

The Second World War was a truly fatal event. It has radically changed the face of the world. The point of view that it was the Second World War that became" the root cause of the catastrophes of the XXI century " has become widespread among historians. Authoritative historians see the First World War as the source of all, or at least most, of the catastrophes of the twenty-first century that would not have occurred without it. The war marked the emergence of a different pace of historical development, when the development of a number of social processes took months and days, which in normal peacetime conditions took years and decades. The very nature of the war was new to European history. It was so total and comprehensive in nature: an unprecedented number of active army mobilizations, a long trench warfare.

A large number of camps were organized by the Allied authorities in occupied Germany to accommodate internees, including former Nazi concentration camps, prisoner-of-war camps and prisons.

46 facilities were used for internment in the American zone, including 37 camps, including the former Nazi death camp Dachau. During 1945-46, up to 25 thousand people (who were in the SS, SS troops (for example, former employees of the 1st SS Panzer Division "Adolf Hitler" and the 2nd SS Panzer Division "Reich", party and state functionaries, Wehrmacht generals and others) were housed in it in four separate zones. On August 31, 1948, the camp was handed over to the Bavarian authorities. The last prisoners left the camp on September 28 of the same year. Later, before the memorial was organized in it, the camp was used to accommodate refugees and homeless people.

\section{MAIN PART}

In the British zone, the largest internment camp was the Staumule camp in the town of Hefelhof, it was designated as Civil Internment Camp No. 5 and was located in a former Nazi prisoner of war camp. From July 1945 to December 1948, up to ten thousand people were interned in the five zones of the Staumule camp. In addition, at the beginning of 1946, an additional zone was built, it contained alleged war criminals of the highest ranks who were brought before the Nuremberg International Military Tribunal. Later, a local prison for minors was located on this territory.

British Civil Internment Camp No. 6 was located in the former Nazi concentration camp Neuengamme. Already on May 27, 1945, 7987 SS men from the deployment zone of the 9th US Army were delivered there. Later, the camp housed Nazi and state functionaries, alleged war criminals and persons allegedly posing a danger to the occupation authorities, mainly from Hamburg and Schleswig-Holstein. On August 13, 1948, the camp was handed over to the authorities of Hamburg, after reconstruction it housed the city prison Vierlande, JVA XII.

The next by number, that is, Civil Internment Camp No. 7 were:

* from November 1945 to September 1946, Camp Roosevelt was a former Nazi prison camp (Russian camp) Stammlager VI A in the city of Hemer (by the end of 1944, there were up to 100 thousand Soviet prisoners of war working in the nearest coal mines in" VI A");

- from October 1946 to December 1947-the Ezelheide camp, organized in the former German prison camp Stammlager VI K (326) near the town of Schloss-HolteStuckenbrock (according to various sources, from 15 to 70 thousand Soviet prisoners of war died in VI K (326)). 
CURRENT RESEARCH JOURNAL OF HISTORY

(ISSN -2767-472X)

VOLUME 03 ISSUE 01 Pages: 1-5

SJIF IMPACT FACTOR (2021: 5. 505)

OCLC - 1243560778 METADATA IF - 6.458

Crossref $d$
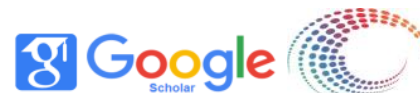

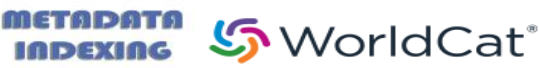

Publisher: Master Journals

British Civil Internment Camp No. 9 is a former concentration camp Esterwegen (one of the first KTS in the north-west of Germany).

Smaller internment camps were located: in Sandbostel in the former Nazi prison camp Stammlager X B, in Westertimke, in Fallingbostel.

In the resort town of Bad Nendorf, from June 1945 to July 1946, the British camp was located in a bathhouse. In addition to high-ranking officials, the leadership of the NSDAP, diplomats, Abwehr officers, persons suspected of spying for the Soviet Union were also held at this highly classified facility. There were originally ten internment camps in the Soviet zone, subordinate to the Department of Special camps of the NKVD of the USSR:

- Special camp No. 1 in Muhlberg in the former Nazi prison camp Stammlager IV B

- Special camp No. 2 on the territory of the Buchenwald concentration camp

- Special camp No. 3 in Hohenschenhausen (Berlin) (later-Stasi labor camp)

- Special camp No. 4 in Bautzen

- Special camp No. 5 in Ketschendorf (Furstenwald)

- Special camp No. 6 in Yamlitz (Liberose district, from September 1945); from May to September 1945 - in Frankfurt am Oder

- Special camp No. 7 in Oranienburg (on the territory of the Sachsenhausen concentration camp) from August 1945; from May to August 1945-in Vernuchen

- Special camps No. 8 and No. 10 in Torgau

- Special camp No. 9 in Funfeichen (Neubrandenburg).

- Also, the transit prison No. 10 in Torgau and the prison for convicted Germans in Strelitz were subordinate to this department.

The number of special camps decreased as their contingent was reduced, and in 1948 there were only three camps left, which were assigned a new numbering: special camp No. 1-Sachsenhausen, No. 2-Buchenwald, No. 3-Bautzen. On September 28, 1949, the Politburo of the Central Committee of the CPSU (b) decided on the procedure for the release of some prisoners from special camps and the transfer of the rest of the special contingent to the German authorities (RGANI. F. 89. List 75. d. 19. I. 9. Certified copy. Extract from the minutes No. 71 of the meeting of the Politburo of the Central Committee of the CPSU (b) on the possibility of releasing some prisoners from the camps of the USSR Ministry of Internal Affairs in Germany and on the transfer of the remaining prisoners to the German authorities. September 28, 1949). The transfer of the camps was made in January 1950.

In the American occupation zone in 1945-48, 3,887 investigations were carried out, 489 trials were conducted by military tribunals (at the place of holding, they were called the "Dachau Trials" over those accused of war crimes and crimes against humanity. Of the 1,672 accused, 426 were sentenced to death. Those sentenced to various terms of imprisonment served their sentences no more than until the end of the 1950s, when all of them were released.

In the Soviet occupation zone in mid-1948, a joint commission of the SVAG, the MGB, and the Ministry of Internal Affairs, which examined over 43 thousand cases, decided to release 27'749 arrested. These were mainly persons suspected of having links with the Nazis, whose guilt was found insignificant, 756 were sentenced to death and executed, 45'261 were released, 12'770 were deported to the Soviet Union for work, the status of 6'680 was changed to prisoners of war.

By November 1946, special camp No. 3 Berlinhoenschenhausen was disbanded. This decision was initiated by the military commandant of the Soviet sector of the occupation of Berlin, Major General A. G. 
CURRENT RESEARCH JOURNAL OF HISTORY

(ISSN -2767-472X)

VOLUME 03 ISSUE 01 Pages: 1-5

SJIF IMPACT FACTOR (2021: 5. 505)

OCLC - 1243560778 METADATA IF - 6.458

Crossref do
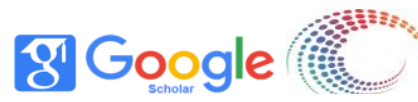

metapata (5) WorldCat

Publisher: Master Journals

Kotikov. In his address to the commander-in-chief of the SVAG, V. D. Sokolovsky, in September 1946, he formulated one of the reasons for the need to liquidate this camp: "The camp cemetery is located near the camp and is not guarded by anyone. Germans freely pass by the camp and the cemetery and can enter the cemetery both during the day and at night. Several hundred corpses are randomly buried in the cemetery, while some of them are buried in craters and various pits. In this situation, the activities of the camp can become widely known not only to the residents of Berlin, but also to other states. " 49 This decision also revealed another significant problem of the functioning of special camps. As it turns out later, the fears of the Soviet leadership that information about their existence will spread in the West and undermine the propagandized image of a democratic state being built in East Germany will become one of the reasons for the disbandment of special camps. But even then, the fact of their existence could not be completely hidden. Back in March 1946, the political adviser to the Commander-in-Chief of the SVAG, V. S. Semyonov informed Serov that there were reports in English newspapers that "the Sachsenhausen and Buchenwald concentration camps and some others have again been turned into places of residence of political prisoners, mainly from the opposition Social Democrats"50. It was impossible to hide these facts from the East German public. In any case, it is known that the leadership of the Communist Party of Germany was aware of the existence of some special camps. The secretary of the KPD, Wilhelm Pik, visited special camp No. 4 in Bautzen at least once in August 1946. Sviridov reported this to Serov in a special message. 51 In addition to the special camp in Berlin, the Strelitz prison was liquidated in November 1946. Germans convicted by Soviet military tribunals were held there - a new category of prisoners who appeared in special camps in May 1946. They were transferred from Strelitz to a separate prison area of the Sachsenhausen special camp52. At the same time, at the initiative of Sviridov, the Lichtenberg prison in Berlin, which contained, in addition to convicted Germans, and citizens of the SSR53, was transferred to the operational sector of the MGB of Berlin and became its internal prison. In February 1947 , on the initiative of Sviridov and with the approval of Serov, camp No. 8 in Torgau was disbanded.55 Also at the beginning of 1947, with the permission of Serov, it was decided to close camps No. 6 Yamlits near Liberoze56 and No. 5 Ketchendorf 57 . Thus, by the second half of 1947, six special camps out of the original ten remained functioning, with the number of prisoners 58,053 people (as of December 15, 1947)58. At the same time, all ten camps worked only from May to November 1946 , i.e. after the creation of the second camp in Torgau and before the closure of the camp in Berlin. First, after resolving the issue with prisoners of war (separating them from those categories that were sent to special camps in accordance with NKVD order No. 00315), the nature of these camps as special specialized places of detention was finally determined, where two main categories of prisoners were kept - internees and convicted by Soviet military tribunals, who made up a smaller part of the entire contingent. Secondly, by the specified period (or even a little earlier), the failure of the attempt to resume labor mobilization of prisoners of special camps became obvious. Special camps have discovered their complete failure as places of preservation of the labor force. This indicated that the camp policy was mainly determined by situational considerations of expediency, and the price for this, as well as for the low degree of efficiency of managing camps that did not have a clear institutional affiliation, was paid by prisoners - with their health and their lives. The most general analysis of the main decisions of the top leadership of the USSR concerning special camps and the life of prisoners held in them, to a certain extent confirms the idea of "deliberate rejection of any planning" 59 in relation to camp policy in Germany. Both 
CURRENT RESEARCH JOURNAL OF HISTORY

(ISSN -2767-472X)

VOLUME 03 ISSUE 01 Pages: 1-5

SJIF IMPACT FACTOR (2021: 5. 505)

OCLC - 1243560778 METADATA IF - 6.458

Crossref do
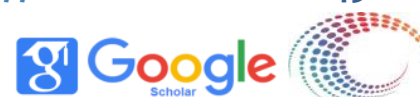

metapara ऽ) WorldCat

Publisher: Master Journals

this commitment on the part of the Soviet leadership to the political conjuncture, and not to a well-thought - out program of action (which was actually absent), and concern about the state of public opinion about themselves were manifested already in 1947, when the fate of special camps in the context of the future of the NWO was not yet obvious.

\section{CONCLUSION}

There is a tendency to close some special camps to improve the condition and make others more compact. And although this did not solve the main shortcomings in their work, and the contingent continued to be in an extremely difficult physical and moral situation, the very instability of the camp network created by the end of 1945 is very indicative. In this regard, as well as the fact that by the end of the third year of the existence of the special camps did not have specific instructions for their work and continued to experience a chronic shortage in the number and quality of soldiers and officers serving there, only a small part of whom were career officers of the Ministry of Internal Affairs, the inevitability of restructuring their activities in one form or another became obvious. The aggravated "German question" will make its own adjustments to the process of transformation of special camps and will largely determine the nature of these changes in 1948-1950.

\section{REFERENCES}

1. Rosenberg A. Entstehung und Geschichte der Weimarer Republik. Frankfurt a.M., 1983. - S. 67, 73.

2. Völker U. Zur inneren Revolutionisierung der wilhelmischen Gesellschaft des Jahres 1918 // Kriegsende 1918. Ereignis, Wirkung, Nachwirkung. München, 1999. - S. 273.

3. Die Arbeiterschaft im neuen Deutschland / Hrsg. Von F. Timmel u. C. Legin. Leipzig, 1915. - S. 17.
4. F. Scheidemann believed that a new orientation of domestic policy should take place, "of course", after the war (Die Arbeiterschaft im neuen Deutschland... S. 58).

5. Fischer F. Hitler war kein Betriebsunfall. Aufsätze. München, 1992. - S. 166.

6. Keil W. Erlebnisse eines Sozialdemokraten. 2 Bde. Stuttgart, 1947-1948. Bd. 1. - S. 302.

7. Халикулова, Хулькар Юлдашевна. "УЧАСТИЕ УЗБЕКИСТАНА В ПАРАЛИМПИЙСКИХ ИГРАХ (20042014 гг.)." Вестник развития науки и образования 6 (2014): 70-75.

8. Халикулова, Хулкар Юлдашевна. "Государственная политика Узбекистана в сфере поддержки инвалидов." Актуальные вопросы современной науки и образования (2016): 99-102.

9. Халикулова, Хулкар Юлдашевна. "Функционирование дошкольных учреждений для детей с ограниченными возможностями (19912013 гг.)." Вестник науки и образования 10 (22) (2016).

10. Халикулова, Хулкар Юлдашевна. "История развития толерантного отношения к инвалидам на основе изучения письменных источников восточных мыслителей Средней Азии." Проблемы современной науки и образования 12 (54) (2016).

11. Халикулова, Х. Ю. "ИСЛАМ И ТРАДИЦИОННЫЕ ЦЕННОСТИ В ОТНОШЕНИИ К СОЦИАЛЬНО УЯЗВИМЫМ СЛОЯМ НАСЕЛЕНИЯ." ИДеаЛЫ И ценности ислама в образовательном пространстве XXI века (2016): 257-259.

12. Халикулова, Хулкар Юлдашевна. "ОБРАЗОВАНИЕ ДЕТЕЙ В СПЕЦИАЛИЗИРОВАННЫХ ШКОЛАХ И ШКОЛАХ ИНТЕРНАТАХ (1991-2014Г)." Theoretical \& Applied Science 5 (2016): 40-43.

13. Xulkar, Xolikulova. "Social protection of people with disabilities in Uzbekistan after State Independence." Humanities and Social Sciences in Europe: Achievements and Perspectives (2015): 29. 